\title{
Analisis Strategi Kreatif dan Tujuan Konten Youtube (Studi Kasus Konten prank Yudist Ardhana)
}

\author{
Shera Aske Cecariyani, Gregorius Genep Sukendro \\ Sheracecariyani@gmail.com geneps@fikom.untar.ac.id \\ Fakultas Ilmu Komunikasi Universitas Tarumanagara
}

\begin{abstract}
Youtube has become one of the favorite media in the community. Many content creators who use YouTube as a place to express their ideas and creativity in the content they present. Content that is currently in great demand by content creators is prank. Prank contains a video of a prankster who is trying to beat someone. One of the content creators who made pranks was Yudist Ardhana. The author is interested in analyzing prank content made by Yudist Ardhana because the prank he made is very interesting and unique. The purpose of this study was to find out the creative strategies and objectives carried out by Yudist Ardhana in the prank content that was made. The theoretical basis used in this study covers creative strategy theory, basic logic, humor and content. The research method used in this study was qualitative with a descriptive case study approach. In this study the author wants to know the creative strategies and objectives of Yudist Ardhana's prank content through interviews, observations and other matters related to this research. It can be concluded, the creative strategy of prank content made by Yudist Ardhana is a strategy that is unique and different from the others because Yudist Ardhana strives to modify his content with Yudist Ardhana's own characteristics, so that the viewers are entertained and not bored with the prank content they present. And Yudist Ardhana's goal to entertain was successful, which was seen from the reaction of the person watching the video and also from the number of video viewers. Although the number of likes on Yudist Ardhana's videos is not as many as the number of viewers, because people who watch and feel entertained, not all will press the likes of the video presented by Yudist Ardhana.
\end{abstract}

Keywords: Yudist Ardhana, Creative strategy, Prank content

\begin{abstract}
Abstrak
Youtube telah menjadi salah satu media favorit di kalangan masyarakat. Banyak konten creator yang menggunakan youtube sebagai tempat untuk menuangkan ide serta kreativitasnya dalam konten yang disajikannya. Konten yang saat ini banyak diminati oleh konten creator adalah prank. Prank berisikan video seorang prankster yang sedang menjahili seseorang. Salah satu konten creator yang membuat prank adalah Yudist Ardhana. Penulis tertarik untuk menganalisa konten prank yang dibuat oleh Yudist Ardhana karena prank yang ia buat sangat menarik dan unik. Tujuan dari penelitian ini adalah untuk mengetahui strategi kreatif dan tujuan yang dilakukan oleh Yudist Ardhana dalam konten prank yang dibuat. Dasar teoritik yang digunakan dalam penelitian ini mencangkup teori strategi kreatif, logika dasar, humor dan konten. Metode penelitian yang digunakan dalam penelitian ini adalah kualitatif dengan pendekatan studi kasus deskriptif. Dalam penelitian ini penulis ingin mengetahui strategi kreatif dan tujuan konten prank Yudist Ardhana melalui wawancara, observasi dan hal-hal lain yang terkait dengan penelitian ini. Dapat disimpulkan, strategi kreatif konten prank yang dibuat oleh Yudist Ardhana merupakan strategi yang terbilang unik dan beda dari yang lainnya karena Yudist
\end{abstract}


Ardhana berusaha untuk memodifikasi kontennya dengan karakteristik Yudist Ardhana Sendiri, sehingga membuat para viewers-nya terhibur dan tidak bosan dengan konten prank yang disajikannya. Dan tujuan Yudist Ardhana untuk menghibur berhasil, yang terlihat dari reaksi orang yang menonton videonya dan juga dari jumlah viewers videonya. Meskipun jumlah like pada video Yudist Ardhana tidak sebanyak jumlah viewersnya, karena orang yang menonton dan merasa terhibur tidak semuanya akan menekan like pada video yang disajikan oleh Yudist Ardhana.

Kata Kunci: Yudist Ardhana, strategi kreatif, konten prank

\section{Pendahuluan}

Dunia teknologi sekarang semakin berkembang. Dengan seiring berjalannya waktu teknologi pun mengalami perkembangan yang cukup besar. Terdapat banyak hal baru yang disebabkan oleh teknologi salah satunya adalah munculnya media baru. Denis McQuail dalam bukunya Teori Komunikasi Massa (1987 : 16-17), menyatakan media baru sebagai media telematik yang merupakan perangkat teknologi elektronik yang berbeda dengan penggunaan yang berbeda pula. Dalam penyebarannya menggunakan teknologi komputer dengan jaringan internet, sehingga dapat diakses dengan mudah, cepat dan di mana saja. Dalam media baru kita dapat mengakses berbagai macam informasi, hiburan dan sebagainya.

Munculnya media baru sangatlah memudahkan setiap orang untuk mencari informasi yang diinginkan tanpa adanya batasan. Selain dapat mengakses informasi dan hiburan, kita juga dapat menyebarkan informasi pada media baru atau media sosial. Informasi yang disebarkan bisa berupa infografis, gambar dan juga video. Saat ini penyebaran informasi yang banyak diminati adalah berupa gambar dan video. Tempat penyebaran informasi gambar dan video yang paling banyak diakses adalah Youtube.

Youtube adalah salah satu media penyebaran informasi yang banyak diminati oleh masyarakat di Indonesia. Di Indonesia sendiri sudah banyak orang yang menjadikan Youtube sebagai tempat untuk mencari nafkah yaitu menjadi seorang youtuber. Seorang youtuber memiliki channel yang di dalamnya terdapat kontenkonten yang berbeda seperti vlog, tutorial, memasak, review, prank dan sebagainya. Tentunya konten yang telah dipilih oleh seorang youtuber harus memiliki ciri khas dan kereatifitas tersendiri. Menurut Kamus Besar Bahasa Indonesia (KBBI) konten adalah informasi yang tersedia melalui media atau produk elektronik. Penyampaian konten dapat dilakukan melalui berbagai medium baik secara langsung maupun tidak langsung seperti internet, televisi, CD audio, bahkan sekarang sudah melalui telepon genggam (handphone).

Dunia kreativitas di Indonesia sekarang semakin berkembang, salah satunya adalah perkembangan kreativitas pada konten Youtube. Menurut Munandar (2009: 12) kreativitas adalah hasil interaksi antara individu dan lingkungannya, kemampuan untuk membuat kombinasi baru, berdasarkan data, informasi, atau unsur-unsur yang sudah ada atau dikenal sebelumnya, yaitu semua pengalaman dan pengetahuan yang telah diperoleh seseorang selama hidupnya baik itu lingkungan sekolah, keluarga, maupun dari lingkungan masyarakat. Banyak pembuat video Youtube atau yang sering disebut youtuber yang ramai-ramai bersaing kekreativitasan dalam membuat konten yang diharapkan mampu menarik perhatian masyarakat. Kreativitas merupakan kunci utama dalam pembuatan konten, sadar tidak sadar ketika satu 
konten kreatif yang disukai banyak orang dibuat pasti kedepannya akan banyak yang membuat konten yang menyerupai dalam jangka waktu yang lama. Konten yang kreatif biasanya akan lebih banyak mendapatkan respon dari masyarakat.

Menurut Fibriyani Elastria, Head of Consumer Marketing Google Indonesia, ada beberapa konten yang paling diminati masyarakat. Posisi pertama yang paling diminati adalah musik. Lalu diikuti oleh entertainment atau hiburan, seperti komedi, vlog dan prank. Konten lain yang juga banyak peminatnya adalah tutorial seperti beauty dan makeup tutorial. (https://inet.detik.com/cyberlife/d-4191950/kontenyoutube-apa-sih-yang-paling-digemari-netizen diakses tanggal 26 september 2018 pukul 11.23 WIB).

Dari banyaknya konten Youtube, fenomena prank atau tindakan jahil yang berupa jebakan sudah banyak diminati oleh para youtuber sejak lama dan dijadikan salah satu konten favorit yang banyak dilakukan oleh youtuber. Salah satu youtuber yang membuat konten prank yaitu Yudist Ardhana, seorang youtuber asal Bali.

Dari semua prank yang dilakukan terdapat satu prank yang sangat menarik perhatian, yaitu prank ke SPBU naik mobil mainan dan prank Hey Tayo. Prank yang dilakukannya bisa dibilang prank yang tidak masuk akal dan unik. Prank tersebut dinyatakan tidak masuk akal dikarenakan prank tersebuat dilakukan di tengah keramaian dengan cara melakukan kejahilan menggunakan mobil mainan dan pergi ke SPBU untuk mengisi bensin padahal mobilnya adalah mobil mainan hingga membuat kebingungan petugas-petugas SPBU tersebut. Selain itu, prank yang Yudist Ardhana buat juga terbilang menarik, karena ia tidak hanya membuat prank saja tetapi prank tersebut digabungkan dengan sulap, social experiment maupun vlog sehingga membuat banyak orang tertarik untuk menontonnya. Menarik dalam hal ini sendiri dalam Kamus Besar Bahasa Indonesia berarti menyenangkan (menggirangkan, menyukakan hati karena indahnya, cantiknya, bagusnya, dan sebagainya), memengaruhi atau membangkitkan hasrat untuk memperhatikan (mengindahkan dan sebagainya). Selain itu jika dilihat Yudist Ardhana adalah youtuber yang dalam channelnya lebih memilih konten prank yang juga dikombinasi dengan vlog, social experiment dan juga sulap. Yudist Ardhana sendiri sekarang telah memiliki satu juta subscriber pada channel youtube nya.

Berdasarkan apa yang sudah dijelaskan di atas, maka penulis membuat rumusan masalah: "Apa saja strategi kreatif dan tujuan konten Youtube Yudist Ardhana?"

\section{Metode Penelitian}

Metode penelitian yang digunakan penulis untuk menganalisa strategi kreatif dan tujuan dalam konten Youtube adalah berupa metode penelitian kualitatif. Deniz dan Lincoln (dalam Moleong, 2009: 5) menyatakan bahwa penelitian kualitatif adalah penelitian yang menggunakan latar alamiah, dengan maksud menafsirkan fenomena yang terjadi dan dilakukan dengan jalan melibatkan berbagai metode yang ada. Metode yang biasanya dimanfaatkan adalah wawancara, pengamatan, dan pemanfaatan dokumen.

Penelitian ini, peneliti menggunakan metode penelitian kualitatif dengan pendekatan studi kasus. Menurut Nawawi (dalam Fajarwati, 2011: 26) penelitian studi kasus memusatkan diri secara intensif pada satu objek tertentu yang mempelajarinya sebagai suatu kasus. 
Dalam penelitian ini yang menjadi subjek penelitian adalah seorang youtuber, yaitu Yudist Ardhana, dan Welldy Handoko CEO dan Founder www.rekamindonesia.id, sebagai narasumber kedua dalam penelitian ini.

Dalam penelitian ini, peneliti menggunakan beberapa metode pengumpulan data untuk dapat mengumpulkan data dan juga informasi yang lebih dalam dengan berbagai cara, yaitu wawancara, observasi, studi kepustakaan, dan penelusuran data online.

Teknik analisa data yang digunakan pada penelitian ini adalah tenik analisis data kualitatif Miler dan Huberman. Menurut Miler dan Huberman (1992) terdapat 3 teknik analisis data yaitu reduksi data, penyajian data, dan kesimpulan atau verifikasi (Gunawan, 2014: 210-211). Salah satu cara penting dan mudah dalam uji keabsahan hasil penelitian adalah dengan melakukan triangulasi. Untuk itu teknik triangulasi merupakan salah satu sarana bagi penelitian kualitatif dalam menguji keabsahan data sebagaimana diungkapkan Moleong (2011: 330) mengenai triangulasi, yaitu teknik pemeriksaan keabsahan data yang memanfaatkan sesuatu yang lain di luar data itu untuk keperluan pengecekan atau sebagai pembanding terhadap data itu. Dalam penelitian ini penulis menggunakan langkah pengujian keabsahan, yaitu triangulasi dengan sumber data.

\section{Hasil Temuan dan Diskusi}

Temuan penelitian yang dilakukan peneliti dalam hal ini merupakan konten video youtube merupakan perwujudan dari komunikasi massa yang dimana di definisikan sebagai proses penggunaan medium massa untuk mengirim pesan kepada audien yang luas untuk tujuan memberi informasi, menghibur, atau membujuk (John Vivian, 2008: 450). Sesuai dengan salah satu fungsi komunikasi massa menurut Jay Black dan Frederick C. Whitney (1988) yaitu to entertain (memberi hiburan), konten prank youtube Yudist Ardhana memenuhi fungsi komunikasi massa untuk memberi hiburan kepada viewers-nya sehingga mereka merasa terhibur dengan sajian videovideo yang diberikan oleh Yudist Ardhana.

Selain untuk menghibur dan juga untuk bersaing dengan youtuber lainnya, strategi yang dilakukan oleh Yudist Ardhana juga merupakan suatu kegiatan untuk meraih targetnya. Target yang ingin ia raih secara tidak langsung terlihat bahwa ia ingin mendapatkan jumlah subscriber yang banyak, ia juga ingin konten video yang ia buat dapat dilihat oleh banyak orang. Target lainnya yang terlihat secara tidak langsung adalah dengan membuat konten video prank ia mendapatkan tawaran kerjasama untuk beriklan melalui konten prank pada channel Youtube miliknya.

Strategi Kreatif yang dilakukan Yudist Ardhana diwujudkan dengan menjadi yang pertama, beda dari yang lainnya. Hal ini sesuai dengan yang dinyatakan oleh Creative Education Foundation, kata-kata "yang beda yang belum pernah ada yang buat" disini bukan berarti harus membuat karya baru, orisinil tetapi juga bisa membuat karya yang sudah ada tetapi dimodifikasi sesuai dengan karakteristik masing-masing, shingga menjadikannya seperti sesuatu yang baru. Hal ini juga sesuai dengan ciri-ciri kreativitas menurut Pedoman Diagnostik Potensi Peserta Didik (Depdiknas 2004: 19) dalam Nurhayati (2011: 10) ciri-ciri kreativitas antara lain:

a. Menunjukan rasa ingin tahu yang luar biasa,

b. Menciptakan berbagai ragam dan jumlah gagasan guna memecahkan persoalan. 
Shera Aske Cecariyani, Gregorius Genep Sukendro: Analisis Strategi Kreatif dan Tujuan Konten Youtube (Studi Kasus Konten prank Yudist Ardhana)
c. Berani mengambil risiko
d. Suka mencoba
e. Peka terhadap keindahan dan segi estetika dari lingkungan.

Konten prank yang dibuat Yudist Ardhana merupakan strategi kreatif yang dibilang berani, suka mencoba dan juga berani menggambil resiko. Seperti halnya salah satu ciri kreativitas yang dikemukakan oleh Supriadi (1994) yaitu ciri-ciri afektif (non-aptitude) ialah ciri-ciri yang lebih berkaitan dengan sikap atau perasaan yang meliputi rasa ingin tahu, bersifat imajinatif, merasa tertantang oleh kemajemukan, sifat berani mengambil resiko dan sifat menghargai. Konten yang dibuat Yudist Ardhana bersifat imajinatif, dia ingin mengetahui reaksi orang-orang yang dituangkan kedalam prank yang imajinatif yang berbeda dari yang lainnya.

Seperti yang dikatakan pada teori konten oleh pengguna (user generated content) yang merupakan salah satu karakteristik media sosial, menunjukan bahwa di media sosial konten sepenuhnya milik dan berdasarkan kontribusi pengguna atau pemilik akun. Konten Youtube sepenuhnya ditentukan dan dibuat oleh content creator. Yudist Ardhana merupakan pengguna youtube yang membuat sendiri konten di channel youtube-nya. Dalam channel youtube-nya ia berlaku sebagai produser, pembuat ide dalam membuat konten-konten di channel Youtube miliknya.

Prank merupakan kegiatan menjahili seseorang yang bisa dibilang kurang masuk diakal. Yudist Ardhana sendiri mengartikan prank sebagai semacam kegiatan becandaan yang dilakukan dengan kegiatan. Jadi jokes itu ada banyak tipe tapi untuk prank itu harus dengan aktifitas, jokes-nya berupa aktivitas. Aktivitas yang dilakukan tidak logis atau tidak sesuai penalaran seperti yang di kemukakan oleh Soekadijo (1994: 3,11) bahwa Kata "logika" sering terdengar dalam percakapan sehari-hari, biasanya dalam arti "menurut akal". Akan tetapi logika sebagai istilah berarti suatu metoda atau teknik yang diciptakan untuk meneliti ketepatan penalaran. Penalaran adalah suatu bentuk pemikiran. Video prank yang dibuat oleh Yudist Ardhana terbilang tidak masuk di akal dikarenakan kebanyakan videonya ia secara tidak langsung memberi penalaran yang tidak dapat diterima menurut akal dengan melakukan kegiatan yang memperlihatkan dia seperti orang bodoh atau orang stres. Dengan demikin dapat dikatakan bahwa video prank yang dia buat bisa dibilang tidak masuk akal karena hal-hal bodoh yang ia lakukan yang tidak masuk dalam penalaran sehari-hari. Namun hal tersebut juga menjadi salah satu strategi kreatif yang dimilikinya karena dengan begitu konten Youtube dia menjadi unik dan berbeda dari yang lainnya.

Konten video prank yang menghibur terdapat humor atau kelucuan di dalamnya. Kelucuan juga selalu kena-mengena dengan hal-hal yang tidak wajar atau umum. Yang wajar dan umum, tidak memerlukan perbaikan atau tidak lagi menyediakan wadah untuk menjadi lucu. Hal-hal yang aneh dan nyeleneh dapat menjadikan humor (Setiawan, 1990). Sesuai dengan teori tersebut dalam konten video prank berisikan kelucuan yang tidak wajar, aneh dan nyeleneh seperti yang dikatakan oleh Setiawan. Begitu pun prank yang dibuat oleh Yudist Ardhana, dengan strateginya untuk menjadi yang unik dan menjadi yang pertama konten prank yang disajikannya banyak yang berisikan kelucuan yang tidak wajar, aneh dan nyeleneh.

Yudist Ardhana juga suka melakukan hal yang bodoh di konten prank nya. Hal bodoh disini maksudnya adalah melakukan hal yang tidak wajar, yang aneh sehingga membuat orang lain tertawa. Hal tersebut juga bisa dibilang merupakan strategi 
khusus yang dilakukan oleh Yudist Ardhana agar viewers-nya tidak bosan dan tetap menjadikan channel-nya dilihat terus oleh viewers-nya.

Kelucuan atau humor untuk menghibur dan terhibur merupakan kebutuhan manusia. Ada juga fungsi dari humor menurut Sujoko (1982) yaitu:

1) Melaksanakan segala keinginan dan segala tujuan gagasan atau pesan.

2) Menyadarkan orang bahwa dirinya tidak selalu benar.

3) Mengajar orang melihat persoalan dari berbagai sudut.

4) Menghibur.

5) Melancarkan pikiran.

6) Membuat orang mentoleransi sesuatu.

7) Membuat orang memahami soal pelik.

Terlihat dari teori tersebut konten prank Yudist Ardhana memenuhi beberapa fungsi dari humor tersebut. Prank yang dilakukan merupakan usaha Yudist Ardhana untuk menghibur para viewers-nya. Viewers Yudist Ardhana sudah merasa terhibur dengan kelucuan atau humor yang diberikan.

Namun pendapat berbeda yang dikemukakan oleh key informant yang merupakan seorang ahli dalam pembuatan konten video. Menurut ia konten prank yang dibuat oleh Yudist Ardhana biasa saja, karena menurutnya apakah video tersebut menghibur atau tidak dilihat dari latar belakang individu yang menontonnya. Menurut ahli, video yang disajikan biasa saja karena niat pembawa cerita di video hanya sekedar mengajak yang menontonnya melihat reaksi yang dilakukannya.

Dari perbedaan pendapat yang terlihat dapat diketahui bahwa fungsi humor yang sekaligus merupakan fungsi komunikasi massa yaitu untuk menghibur dapat diartikan berbeda-beda tergantung individu yang melihatnya. Kreativitas pun dapat diartikan berbeda oleh setiap orang. Maka dari itu strategi kreatif sangat dibutuhkan dalam kegiatan apapun. Strategi kreatif merupakan kunci dari pembuatan sebuah karya. Tinggal pada saat perwujudannya di dalam sebuah karya tersebut, apakah strategi tersebut dapat disajikan dengan baik. Namun kembali lagi pada individu yang melihat, ada suatu karya yang sudah disajikan demikian rupa kreatifnya akan tetapi tidak menutup kemungkinan akan mendapat respon yang mengatakan bahwa karya tersebut tidak kreatif dan tidak menghibur.

Dilihat dari hasil wawancara, peneliti mengidentifikasi strategi yang dilakukan oleh Yudist Ardhana dalam pembuatan konten prank di channel youtubenya adalah harus menjadi unik. Terlihat dari video yang ia buat, kebanyakan ia menyajikannya dengan cara yang unik yaitu mengabungkan konten prank dengan konten lainnya seperti sulap, vlog, social experiment dan sebagainya yang tidak dibuat oleh youtuber lainnya. Yudist juga memiliki strategi kreatif untuk menjadi yang berbeda dan menjadi yang pertama dalam pembuatan video prank-nya. Dia selalu membuat konten prank yang belum pernah dilakukan oleh youtuber lain di Indonesia. Seperti video prank sulap dan juga prank mobil mainan yang ia buat, ia merupakan youtuber pertama di Indonesia yang membuat konten prank seperti itu. Dan strategi untuk menjadi yang pertama menjadikan konten prank yang ia buat pun menjadi viral dan menjadi pelopor sehingga banyak orang yang mengikutinya. Salah satu video prank yang ia buat yaitu Hey Tayo menjadi viral sampai diketahui orang-orang di luar negeri.

Pembawaan karakter yang dilakukan oleh Yudist Ardhana juga merupakan salah satu strategi kreatif yang ia buat. Karena menurutnya karakter seseorang merupakan nilai jual dari channel youtube itu sendiri. Karakter yang dibawakan Yudist Ardhana membuat para viewers-nya terhibur dan tidak bosan untuk menonton 
di channel youtubenya. Tujuan Yudist Ardhana untuk menghibur target viewers-nya juga sudah terwujud. Terlihat dari tanggapan viewers-nya yang menyatakan bahwa konten prank-nya sudah bisa membuat tertawa. Dan juga terlihat dari respon jujur dari orang-orang yang tidak direkayasa pada videonya yang memberikan hiburan tersendiri bagi viewers video tersebut.

\section{Simpulan}

Berdasarkan hasil analisa strategi kreatif dan tujuan konten prank yang dilakukan oleh Yudist Ardhana, peneliti menyimpulkan beberapa hal, anatara lain: Strategi kreatif yang telah dilakukan oleh Yudist Ardhana dengan cara menjadi unik, berbeda dari yang lainnya dan juga menjadi yang pertama sudah cukup kreatif, karena sudah bisa membuat video prank yang ia buat menjadi viral dan menjadi pelopor bagi youtuber lainnya. Menjadi yang pertama dalam hal ini berarti bukan hanya ia yang membuat karya orisinil, melainkan ia juga membuat karya dengan meniru tetapi ia modifikasi dengan ciri khas Yudist Ardhana sendiri dan juga membawakan konten videonya dengan karakter sendiri. Strategi yang Yudist Ardhana lakukan juga termasuk strategi ambil, tiru, dan modifikasi seperti pada video prank mobil yang ia buat, yang terinspirasi dari prank orang luar negeri lalu ia buat dan ia modifikasi dengan caranya tersendiri.

Dengan pembawaan karakter Yudist Ardhana mampu bersaing dengan youtuber lainnya dan menjadikan channel Youtube yang dikelolanya menjadi salah satu pilihan viewers-nya yang tidak membosankan.

Tujuan Yudist Ardhana untuk menghibur sudah tercapai, dengan membuat para viewers-nya tertawa saat menonton video prank-nya. Namun terdapat perbedaan pendapat antara ahli dengan viewers Yudist Ardhana. Menurut ahli video yang disajikan kurang menghibur, karena menurut dia menghibur atau tidak tergantung pada latar belakang individu yang melihatnya. Namun kembali lagi pada target viewers Yudist Ardhana yang merupakan anak remaja dewasa, strategi yang dia berikan sudah mencapai untuk menghibur target viewers-nya. Tujuan Yudist Ardhana untuk menghibur juga terlihat pada jumlah viewers video yang disajikannya, yaitu mencapai lebih dari satu juta viewers bahkan ada yang sampai belasan juta viewers. Namun dari banyaknya penonton pada video youtube Yudist Ardhana, jumlah like pada videonya tidak sebanyak jumlah viewersnya. Tetapi hal ini dikarenakan banyak orang yang menonton videonya dan merasa terhibur tetapi belum tentu menekan tombol like pada video yang disajikan.

Dalam strategi kreatifnya, Yudist Ardhana juga memikirkan efek yang akan timbul jika dia membuat konten prank-nya. Dan ia juga memikirkan dengan baik premis dari video yang akan dia buat. Setelah premisnya ditemukan selanjutnya ia melakukan proses kreatif bersama timnya.

Selain untuk menghibur terlihat juga bahwa Yudist Ardhana juga memiliki tujuan lain yaitu, ia sangat mengejar jumlah subscriber pada channel Youtubenya, ia juga mengejar jumlah viewers pada video yang ia sajikan. Seperti pada video bakar biskuit, karena jumlah viewersnya banyak maka Yudist membuat video bakar-bakar versi lainnya. Terlihat juga ia menjadikan Youtube sebagai tempat ia untuk bekerja dan mencari nafkah yang didapatkannya melalui google adsense. Dengan banyaknya tawaran untuk membuat iklan, itu juga secara tidak langsung bisa menjadikan alasan dan tujuan lain Yudist Ardhana dalam pembuatan kontennya. 


\section{Ucapan Terima Kasih}

Puji Syukur saya panjatkan kepada Tuhan Yang Maha Esa, karena telah melimpahkan berkat dan rahmat-Nya sehingga saya dapat menyelesaikan laporan penelitian dalam mata kuliah skripsi.

Saya menyadari bahwa penyusunan skripsi ini tidak akan terwujud tanpa adanya bantuan dan dorongan dari berbagai pihak. Oleh karena itu pada kesempatan ini saya ingin menyampaikan ucapan terima kasih kepada orang-orang yang telah membatu saya dalam penyusunan penelitian skripsi ini :

1) Bapak Gregorius Genep Sukendro S.sos.,M.si. selaku dosen pembimbing skripsi.

2) Seluruh Dosen Fakultas Ilmu Komunikasi Universitas Tarumanagara.

3) Kepada sahabat penulis, Avissa Yufen F, Helen, Michael Limantara, Rocky Kurniawan

4) Serta para narasumber yang telah meluangkan waktunya.

\section{Daftar Pustaka}

Bogdan dan Taylor, 1975 dalam J. Moleong, Lexy. (1989). Metodologi Penelitian Kualitatif. Bandung: Remadja Karya.

Denis McQuail. (1987). Mass Communication Theory (Teori Komunikasi Massa). Jakarta: Erlangga.

Miles, Matthew dan Huberman, A. Michael. (1992). Analisis Data Kualitatif: Buku Sumber Tantang Metode-Metode Baru. Jakarta:UI Press.

Moleong, L.J. (2011). Metodologi Penelitian Kualitatif Edisi Revisi. Bandung: PT Remaja Rosdakarya.

Soekadjo. (1994). Logika DasarTradisional, Simbolik, Dan Induktif. Jakarta: PT.Gramedia Pustaka Utama.

Vivian, John. (2008). Teori Komunikasi Massa. Jakarta: Kencana Prenada Group. http://sastra.um.ac.id/wp-content/uploads/2009/10/Sejarah-Teori-Jenis-dan-FungsiHumor.pdf https://library.binus.ac.id/eColls/eThesisdoc/Bab2/2011-2-00436-mc\%202.pdf https://inet.detik.com/cyberlife/d-4191950/konten-youtube-apa-sih-yang-palingdigemari-netizen 